UDC 338.434

DOI: https://doi.org/10.32847/business-navigator.60-19

\author{
Malinoshevska Kateryna \\ Candidate of Economic Sciences \\ Financial Director of «Highline Media» Ltd.
}

Маліношевська К.І. кандидат економічних наук, фінансовий директор

Товариство з обмеженою відповідальністю «Хайлайн Медіа»

\title{
STRATEGY OF DEVELOPMENT OF AGRO-INDUSTRIAL COMPLEX IN THE CONDITIONS OF REGIONALIZATION
}

\begin{abstract}
Malinoshevskaya Kateryna. Strategy of development of agro-industrial complex in the conditions of regionalization. The article investigates the essence of development strategy as an economic category and identifies its features for agricultural enterprises. Problems of strategy construction at the regional level are defined, the estimation of degree of maintenance of development of the enterprises of agrarian and industrial complex in regions of Ukraine on the basic kinds of food with the use of statistical methods is carried out. Methods of liquidation of negative manifestations in agricultural production of the region with introduction of strategic management system in agrarian sector of economy and development of strategic directions of development of agro-industrial complex of regions for the purpose to achieve parameters of maintenance of the activity efficiency level of agro-industrial enterprises are offered.

Key words: strategy, agro-industrial complex, strategic management, strategy of agro-industrial complex development, agrarian enterprises, factors of influence on development of agro-industrial enterprises.
\end{abstract}

Маліношевська К.І. Стратегія розвитку агропромислового комплексу в умовах регіоналізації. У статті досліджено сутність стратегії розвитку як економічної категорії та визначено їі особливості для підприємств АПК. Виявлено фактори, які впливають на формування стратегії розвитку АПК. Визначено проблеми побудови стратегії на регіональному рівні, проведена оцінка ступеню забезпеченості розвитку підприємств АПК в регіонах України за основними видами продовольства з використанням статистичних методів. Досліджено причини зниження рівня розвитку підприємств АПК. Обгрунтований комплекс організаційних, економічних, державних заходів, які забезпечують сталий розвиток суб'єктів АПК, що включає: забезпечення продуктами харчування населення, дотримання стандартів якості при виробництві цих продуктів, захист інтересів вітчизняних товаровиробників, експорт вітчизняної сільськогосподарської продукції на світові ринки. Запропоновано методи ліквідації негативних проявів в сільськогосподарському виробництві регіону з запровадженням в практику системи стратегічного управління в аграрному секторі економіки та вироблення стратегічних напрямків розвитку агропромислового комплексу регіонів з метою досягнення параметрів забезпечення рівня ефективності діяльності підприємств АПК та забезпечення збалансованого функціонування сільського господарства $з$ врахуванням зовнішньоекономічного співробітництва, раціоналізації структури зовнішньої торгівлі. Запропоновані підходи до територіально-галузевих підрозділів праці АПК, які формують спеціалізовані зони по виробництву окремих видів сільськогосподарської продукції, сировини, які забезпечують функціонування вітчизняного агропромислового комплексу. Досліджені теоретико-методологічні основи стратегічного розвитку агропромислового комплексу, що відображають специфіку його трансформації і адаптації до ринку, стратегічне планування розвитку сільського господарства і переробної промисловості в частині таких найважливіших компонентів як вибір стратегій і пріоритетних напрямів їх розвитку, організації, планування, розробки та реалізації комплексних рішень розвитку АПК.

Ключові слова: стратегія, агропромисловий комплекс, стратегічне управління, стратегія розвитку АПК, аграрні підприємства, фактори впливу на розвиток підприємств АПК.

Малиношевська К.И. Стратегия развития агропромышленного комплекса в условиях регионализации. В статье исследована сущность стратегии развития как экономической категории и определены ее особенности для предприятий АПК. Выявлены факторы, которые влияют на формирование стратегии развития АПК. Определены проблемы построения стратегии, проведена оценка степени обеспеченности развития предприятий АПК в регионах Украины по основным видам продовольствия с использованием статистических методов. Исследованы причины снижения уровня развития предприятий АПК. Предложены методы ликвидации негативных проявлений в сельскохозяйственном производстве региона с введением в практику системы стратегического управления в аграрном секторе экономики и выработки стратегических направлений развития агропромышленного комплекса регионов и обеспечения уровня эффективности деятельности предприятий АПК.

Ключевые слова: стратегия, агропромышленный комплекс, стратегическое управление, стратегия развития АПК, аграрные предприятия, факторы влияния на развитие предприятий АПК. 
Formulation of the problem. Sustainable development of the regional complex of agro-industrial complex largely depends on the efficiency of agricultural production. All regions of Ukraine have prospects for further development of the regional agro-industrial complex. In the new economic conditions, the introduction of a system of strategic management in the agricultural sector of the economy as the basis for the survival of the agricultural sector in the long run comes to the fore. In this regard, the scientific novelty of the study is to develop strategic alternatives for the development of agro-industrial regions and choosing the most optimal strategy based on modern strategic diagnosis of agro-industrial production in terms of rural areas of Ukraine.

Analysis of recent research and publications. The problem of developing and implementing a regional development strategy is currently being studied by both domestic and foreign scientists. The importance of strategic development in their works was investigated by Z.N. Bochaieva, I.V. Burakovskyi, A.I. Kredisova, A.A. Mazaraki, T.M. Tsyhankova, T.M. Melnyk, Yu.V. Yakovets. Attention is paid to the study of the essence of strategy as an economic category in the works of V.H. Andriychuk, B.O. Olin, V.R. Sidenko, A.S. Filipenko, D.V. Sheveliov. Considerable attention is paid to the assessment of problems and prospects for the development of the agro-industrial complex of Ukraine. Similar studies have been identified in the works of V.I. Vlasova, V.V. Rokocha, V.I. Hubenko, S.M. Kvasha, P.T. Sabluk, O.A. Fesyna.

However, the issues of development of the agricultural sector of the economy in the context of regionalization of economic processes are still poorly studied. A study of the features and priorities of the regions, one of which is the development of a strategy for the development of agriculture, requires clarification. There are also unresolved issues related to the use of the targeted programs for effective management of agricultural development in the regions.

Formulation of the goals of the article. The study is to analyze the current state of agricultural production in the regions of Ukraine, identify problems with the development of strategy in the regions and justify the need for strategic management of agriculture as a basis for achieving the parameters of development strategy at the regional level.

Presenting main material. The agro-industrial complex is an organizational and economic system that connects the branches of agricultural production, provides procurement, storage, processing and sale of products.

The tasks of the government responsible for the development of agro-industrial complex include the definition and recommendations for the territorial location and specialization of production, the formation of interregional flows of agricultural products, raw materials and food, development of zonal systems of agriculture, information support of agro-industrial production and agri-food market of agro-industrial complex financial resources [1].

Each region has its own specifics of internal space and connection with both internal and external environment.

The objective basis of the economic integrity of the region is a set of interconnected objects of different industries, forming a unique regional complexity, which is a special kind of integration that ensures the development of productive forces of the territory through independent dynamic development of its own economy using available resources (natural, labor, financial). Regional complexity is manifested in a rational combination of branches of specialization and branches of infrastructure, which form the economic core of the region's economy.

The development of agriculture, food and processing industries of the regions will be determined by the needs of providing food to the population of large regional and other cities, including dairy products, pork and poultry. The study and assessment of all factors allows to reveal the mechanism of formation and development of agriculture in the regional agro-industrial complex more fully, to establish the organization of its activities in line with existing opportunities in the region, and to predict long-term structural changes and their parameters (Table 1). Rational allocation of agricultural production, food and processing industries will significantly increase the efficiency of investment in these industries, ensure the integrated development of rural areas, compliance with environmental standards in agricultural production [2].

The analysis of the industry for the last five years shows that the agricultural sector of Ukraine was constantly in a state of ups and downs operates until: $2014:+2.2 \%$, 2015: $-4.8 \%, 2016:+6.3 \%$ 2017: $-2,2 \%, 2018:+8.1 \%$.

Regarding 2019, it can be noted that:

- growth was achieved both in the crop segment $(+1.3 \%)$ and in the livestock segment $(+0.5 \%)$;

- production volumes increased in most (14 out of 24) regions of the country, including Zaporizhzhia $(+23.2 \%)$, Donetsk $(+17.3 \%)$, Luhansk $(+10.7 \%)$ and Dnipropetrovsk $(+7.2 \%)$ regions. Industrial regions, which were not considered agricultural, achieved positive changes and qualitative growth [3].

- in recent years, indicators for the collection of cereals and legumes increased. 75.08 million tons of grains were harvested from an area of 15.28 million hectares, which is $7.2 \%$ more than in 2018 (70.06 million tons). The average yield was 49.1 quintals per hectare (in $2018-47.4$ ). By types of crops, $15 \%$ more wheat (28.3 million tons), $21.2 \%$ - barley ( 8.9 million tons), $110 \%$ - millet ( 0.2 million tons). At the level of last year, the harvest of corn for grain remained at 35.8 million tons $(+0.1 \%)$, as well as oats -0.3 million tons $(+0.8 \%)$. Note that in some regions in terms of grain harvest increased production. For example: in Zaporizhzhia region - by $49.5 \%$, in Donetsk region - by $46.3 \%$, in the Luhansk region - by $24.7 \%$, in Dnepropetrovsk region - by $22.8 \%$, in Mykolaiv area - by $17.1 \% \%$, in Kharkiv region - by $15.3 \%$.

- the large harvest shows that as of January 29, 2020, 35.7 million tons of crops were shipped to foreign recipients, which is 8.4 million tons more than on the same date a year earlier. Projected exports are at least 54 million tons.

- Ukraine became the third largest exporter of agricultural products to the European Union, exporting goods worth more than 7.2 billion EUR a year, second only to the United States (12.3 billion EUR) and Brazil (11.7 billion EUR), and ahead of China, Argentina and Turkey. According to the dynamics of growth of exports of the Ukrainian products to the European markets $+40.6 \%$, in the near future the position of the Ukrainian products will improve.

- Ukraine entered the Top 5 countries in the world exporters of chicken, second only to Brazil, the EU and Thailand (Table 2).

It should be noted that in addition to the above negative consequences of the development of agriculture at the regional level, despite the overall growth of production of 
Factors influencing the formation of agricultural development strategy

\begin{tabular}{|c|c|}
\hline Group of factors & List of factors \\
\hline Macroeconomic factors & $\begin{array}{l}\text { - pricing policy; } \\
\text { - credit policy; } \\
\text { - budget policy } \\
\text { - tax system; } \\
\text { - foreign economic activity; } \\
\text { - social policy. }\end{array}$ \\
\hline Social factors & $\begin{array}{l}\text { - demographic situation; } \\
\text { - employment; } \\
\text { - resettlement; } \\
\text { - social infrastructure; } \\
\text { - urbanization. }\end{array}$ \\
\hline Scientific and technical factors & $\begin{array}{l}\text { - development of science and technology; } \\
\text { - informatization. }\end{array}$ \\
\hline Economic factors & $\begin{array}{l}\text { - supply and demand for agricultural products; } \\
\text { - pricing system; } \\
\text { - production and market infrastructure; } \\
\text { - factors and means of production; } \\
\text { - location of production; } \\
\text { - inter-farm cooperation and integration; } \\
\text { - competition. }\end{array}$ \\
\hline Microeconomic factors & $\begin{array}{l}\text { - professional level training; } \\
\text { - adaptability to the market environment; } \\
\text { - social conditions; } \\
\text { - concentration and specialization; } \\
\text { - forms of organization of production; } \\
\text { - resource security. }\end{array}$ \\
\hline Environmental factors & $\begin{array}{l}\text { - ecological situation in the region; } \\
\text { - system of rational formation of the ecological market; } \\
\text { - availability of environmentally friendly technologies. }\end{array}$ \\
\hline Natural and climatic factors & $\begin{array}{l}\text { - natural resources and natural conditions; } \\
\text { - zonal factors (relief, hydrography). }\end{array}$ \\
\hline
\end{tabular}

certain types of livestock products (live meat - by $4.8 \%$ naturally the result of cutting cattle, eggs - by 3.4\%) decreased significantly in some regions of the country. In Mykolaiv region, sale of meat for slaughter decreased by $10.1 \%$, in Khmelnytsky - by $8.2 \%$, in Odesa - by $8.0 \%$. In Kherson region, egg production decreased by $21.3 \%$, in Odesa - by $19.2 \%$, in Khmelnytskyi - by $5.7 \%$. The situation is even worse with milk production, which decreased in the country by $3.7 \%$ (including in Zaporizhzhia region by $9.8 \%$, in Kyiv - by $8.4 \%$, in Mykolaiv - by $7.9 \%$, in Sumy - by $7.5 \%$, in Vinnytsia - by $7.3 \%$, in Donetsk - by $7.0 \%$, in Zhytomyr - by $6.5 \%$ ). The shortage of Ukrainian raw milk leads to a significant increase in the market presence of imported dairy products. According to the Institute of Agrarian Economics, the value of dairy imports increased from 66.3 million USD in 2017 to 152.2 million USD in 2019 , i.e. 2.3 times. In addition, low production volumes in the agro-industrial complex continue to affect the processing industry. If the volume of agricultural production increased by $1.1 \%$, the volume of food processing industry - only by $0.2 \%$. The development strategy should deepen processing and enter foreign markets with finished products, without exporting raw materials abroad. It is necessary to pay attention to the development of the industry's economy. Total expenditures on agricultural production decreased compared to 2018 by $0.6 \%$ - food prices increased by $8.0 \%$. At the same time, exactly $50 \%$ of agricultural enterprises in January-September 2019 remained unprofitable (on average in the economy this figure was $22.7 \%$ ). The agricultural sector is traditionally in the second half of the list by average wages. The industry is losing workers who go to work abroad on farms. Agricultural machinery needs innovation and modernization, agricultural machinery is declining (in 2019, the production of tractors decreased by $43.5 \%$, plows - by $16.5 \%$, harrows $13.7 \%$, drills - by $10.7 \%$.).

One of the strategic directions of agro-industrial development should be the support of agrarians by the state [4]. In Ukraine, agricultural subsidies in 2018 amounted to 6.3 billion UAH (210 million EUR), in 2019 - 5.9 billion UAH (204 million EUR), and for 2020 - only 4.2 billion UAH. According to the Budget Code, farmers will receive $1 \%$ of agricultural output by the end of 2021, which will reduce this program to a minimum in 11 months, and from the beginning of 2022 - to abandon state support for agriculture.

Let us pay attention to the personnel policy of agro-industrial complex. Redundancies in liquidation are negative factors for the sustainable development of the industry, these experiments on the industry, which provides jobs and livelihoods for more than 5 million employees, are incompatible with the prosperity strategy [3].

The Ukrainian agro-industrial complex forms $10 \%$ of the country's GDP and exports $40 \%$ (in money) of the total volume of goods. The industry still has great potential, which is gradually realizing [4]. 
Table 2

Negative phenomena of agro-industrial complex development and their characteristics

\begin{tabular}{|c|c|}
\hline $\begin{array}{l}\text { Negative phenomena of agro-industrial } \\
\text { complex development (2019) }\end{array}$ & Characteristic \\
\hline $\begin{array}{l}\text { Political results of the government's } \\
\text { work. }\end{array}$ & $\begin{array}{l}\text { The annual growth of the agro-industrial complex was ensured by the results of } \\
\text { the previous government (in January-July } 2019 \text {, the growth of the agro-industrial } \\
\text { complex was }+12.0 \% \text { compared to the same period last year). Under the new } \\
\text { government, the results were in } 9 \text { months: }+5.9 \%, 10 \text { months: }+3.3 \% \text {, } \\
11 \text { months: }+2.4 \%, 12 \text { months: }+1.1 \% \text {. }\end{array}$ \\
\hline $\begin{array}{l}\text { Acquisition of small farmers by large } \\
\text { agricultural holdings. }\end{array}$ & $\begin{array}{l}\text { Small farmers reduced production by } 2.0 \% \text { (including in the crop segment by } \\
1.2 \% \text {, livestock by } 3.5 \% \text { ). In practice, large agrarian businesses are taken into } \\
\text { account. The interests of small and homestead agricultural production, the } \\
\text { development of the cooperative movement, and the breeding of young animals } \\
\text { are neglected by individuals, although their support is emphasized. }\end{array}$ \\
\hline $\begin{array}{l}\text { Regions where a decline in agricultural } \\
\text { production has been recorded. }\end{array}$ & $\begin{array}{l}\text { Crop growers in Odesa region reduced production by } 11.5 \% \text {, Kyiv region by } \\
6.4 \% \text {, Cherkasy region by } 6.0 \% \text {, Vinnytsia region by } 5.1 \% \text {, Ivano-Frankivsk } \\
\text { region by } 4.7 \% \text {, and Poltava region by } 4.3 \% \text {. Livestock in Luhansk region lost } \\
11.2 \% \text { of its volume, Kherson region }-9.3 \% \text {, Zaporizhzhia region }-8.0 \% \text {, Odesa } \\
\text { region }-5.6 \% \text {, Kyiv region }-4.9 \% \text {. Most of these regions have traditionally been } \\
\text { agrarian areas, and the decline in production in this sector threatens to increase } \\
\text { unemployment and labor migration of rural residents to neighboring countries. }\end{array}$ \\
\hline $\begin{array}{l}\text { Crops, the volume of which was } \\
\text { requested in comparison with } 2018 \text { at an } \\
\text { ambiguous rate. }\end{array}$ & $\begin{array}{l}\text { For example, the reduction of grape growing in Ukraine in } 2019 \text { by } 30 \% \\
\text { (or } 141 \text { thousand tons, to } 327 \text { thousand tons), which is the lowest figure in the } \\
\text { history of Ukraine's independence, led to the fact that its processing was reduced } \\
\text { to a record low level ( } 2.2 \text { times - up to } 124.2 \text { thousand tons), resulting in a } \\
\text { significant decline in wine production. In } 2019 \text {, Ukraine was included in the Top } \\
3 \text { importers of Turkish tomatoes with a total value of about } 30 \text { million USD, and } \\
\text { the share of Turkish tomatoes and cucumbers in the Ukrainian market is already } \\
\text { about } 80 \% \text { of their total imports. }\end{array}$ \\
\hline $\begin{array}{l}\text { Reduction of livestock of all (except } \\
\text { poultry) species of farm animals. }\end{array}$ & $\begin{array}{l}\text { The herd of cattle on January } 1,2020 \text { (in just } 12 \text { months) decreased by } 5.7 \% \\
\text { (including cows - by } 5.0 \% \text { ), pigs - by } 4.9 \% \text {, sheep and goats - by } 4.7 \% \text {. In } \\
\text { some regions, the situation is even worse. For the last } 12 \text { months in Zaporizhzhia } \\
\text { region, } 14.3 \% \text { of cattle are slaughtered, in the Kherson region - } 12.1 \% \text {, in } \\
\text { Mykolaiv area }-10.7 \% \text {. The number of sheep in Kherson region decreased by } \\
22.6 \% \text { and in Zhytomyr region by } 16.7 \% \text {. The situation is very difficult with } \\
\text { pigs, the number of which in Lviv region decreased by } 15.9 \% \text {, in Poltava - by } \\
15.1 \% \text {, in Zaporizhzhia - by } 14.0 \% \text {, in Zhytomyr - by } 13.8 \% \text {, in Odesa - by } \\
13.7 \% \text {, in Kherson - by } 12.8 \% \text {, in Mykolaiv - by } 12.4 \% \text {, in Ternopil - by } \\
12.2 \% \text {. The trend of cattle slaughter has not changed for } 28 \text { years. During the } \\
\text { years of independence, the number of cattle decreased } 7.8 \text { times (from } 24,623.4 \\
\text { to } 3,143.8 \text { thousand heads), including cows }-4.6 \text { times (from } 8378.2 \text { to } 1823.0 \\
\text { thousand heads), pigs }-3.4 \text { times (from } 19426.9 \text { to } 5731.1 \text { thousand heads), } \\
\text { sheep and goats }-7.0 \text { times (from } 8418.7 \text { to } 1209.0 \text { thousand heads). }\end{array}$ \\
\hline
\end{tabular}

Currently, regional stabilization and development programs are being developed in many regions, which identify the main directions of regional policy and link them to certain priorities. It is noteworthy that there are usually no legislative documents that describe in detail the goals, main directions, methods of regional agricultural policy. There are also no long-term comprehensive programs adopted at the legislative level. This situation is due to the general instability and reluctance of the administration to perform its duties in conditions of uncertainty [5]. In fact, the regional policy pursued by the regional administration is reduced to the annual publication of resolutions defining the directions and specific amounts of support for industries and various activities of the regional agro-industrial complex. The analysis of regional differences in the implementation of agrarian reform shows that the greatest diversity of forms of ownership is characteristic of areas of high agricultural development. In the regions where the development of farming continues, regional and district associations of farms are actively working, closely cooperating with state agricultural management bodies [6].
According to experts, the model of vertically integrated holdings and corporations is quite promising. New forms of organization of agro-industrial production provide for the creation of territorial branch associations (companies, corporations) in the form of open joint-stock companies and other organizational and legal forms. At the same time, there are significant shortcomings in the establishment and operation of agro-industrial formations caused by the imperfection of the legal framework, in particular the lack of a legal basis for holding companies. In parallel with the creation of agro-industrial associations, order placement systems are being reorganized; agro-industrial complex financing; ensuring the supply of agricultural machinery, spare parts, fuel, agrochemistry; the systems of responsibility of the subjects of production for the used financial and commodity credits are improved [7].

These areas should be complemented by measures to restore the country's food security by giving priority in the domestic market to domestic producers through the establishment of customs regulators for the import of imported 
food; strengthening the regulatory and legal support of the agro-industrial complex in order to prioritize the protection of domestic producers. The most appropriate areas of market relations in the agro-industrial complex of Ukraine are the following: increasing the role of the state in regulating intersectoral relations, forming a system of affordable agricultural credit, procurement and intervention in the market of agricultural products and food; gradual development of market relations as economic conditions and market infrastructure are created; state support of the social sphere of the village [8]. It would be necessary to maximize opportunities to regulate prices within the agro-industrial complex by stimulating the creation of cooperatives, the introduction of marginal coefficients of the ratio of prices for finished products and purchase of agricultural raw materials, setting margins for certain products, retail and wholesale prices. For the dynamic development of infrastructure, it would be appropriate to develop organizational and economic measures to stimulate the creation and operation of a cooperative system of sales, the creation of wholesale food markets, increasing the role of exchanges, financial and industrial groups.
Conclusions. Agrocomplex as one of the most important budget-generating sectors of the economy is able to more than double the volume of agricultural production. The condition for the effective development of the agro-industrial complex is to ensure its adaptation to changes in the external environment, which is possible only within the framework of a strategic approach to agro-industrial complex management. It is necessary to continue improving the mechanisms of co-financing of basic economic measures and programs aimed at the development of agricultural entities, taking into account the solution of national problems of forming a single economic space, equalization of living conditions of the rural population. The strategy for the development of the agricultural sector of the agro-industrial complex of the regions requires the state to provide the main directions and organizational and economic measures to increase its efficiency. Assessment of the level of regional agro-industrial complex will determine the current state of agro-industrial production and develop strategic directions for the development of agro-industrial complex in the region in the near and long term.

\section{References:}

1. Ambrosov V.Ya. (2013) Rynok i stratehiia rozvytku silskohospodarskykh pidpryiemstv [The market and the strategy of development of agricultural enterprises]. Ekonomika APK, vol. 10, pp. 72-79.

2. Honcharov S.M., Kushnir N.B. (2009). Interpretatyvnyi slovnyk ekonomista [Interpretative dictionary of the economist]. Kyiv: Centre of educational literature. (in Ukrainian)

3. Yerokhin S.A. (2002) Strukturna transformatsiia natsionalnoi ekonomiky (teoretyko-metodolohichnyi aspekt) [The structural transformation of national economy (theoretical and methodological aspect]. Kyiv: Svit Znan. (in Ukrainian)

4. Kondratenko N.O. (2010) Startehiia resursozberezhennia rehionalnykh ekonomichnykh system [The resource-saving strategy of the regional rconomic systems]. Kharkiv: NTM. (in Ukrainian)

5. Mazaraki A.A. (2014) Osnovu menedzmentu: a textbook for students of higher educational institutions / A.A. Mazaraki, O.Y. Kuzmin, O.G. Melnik and others; for order. A.A. Mazaraki. Kharkiv: Folio, 2014. 846 p. (in Ukrainian)

6. Melnyk T.M.(2016) Importna zaleznist economiki Ukrainu ta prioritetu selectuvnogo importozamichennya/T.M. Melnyk, K.S. Pugachevska // Economy of Ukraine, no. 4, p. 29-44. (in Ukrainian)

7. Sotnyk I.M., Melnyk L.H., Shapochka M.K., et. al. (2006) Resursozberezhennia ta ekonomichnyi rozvytok Ukrainy. Formuvannia mekhanizmiv perekhodu subiektiv hospodariuvannia Ukrainy do ekonomichnoho rozvytku na bazi resursozberihaiuchykh tekhnolohii [Resource-saving and economic development of Ukraine: the formation of the transition mechanisms for business entities of Ukraine to the economic development on the basis of resource-saving technologies]. Sumy: Universytetska knyha. (in Ukrainian)

8. The statistical publication (2015) Zovnishnia torhivlia Ukrainy tovaramy ta posluhamy u 2010-2014 rokakh [External trade of Ukraine in 2010-2014]. Available at: http://www.ukrstat.gov.ua (accesse 10 September 2020).

\section{Список використаних джерел:}

1. Амбросов В.Я. Ринок і стратегія розвитку сільськогосподарських підприємств. Економіка АПК. 2013. № 10. C. $72-79$.

2. Гончаров С.М., Кушнір Н.Б. Тлумачний словник економіста / за ред. проф. С. М. Гончарова. Київ : Центр учбової літератури, 2009. 264 с.

3. Срохін С.А. Структурна трансформація національної економіки (теоретико-методологічний аспект) : Наукова монографія. Київ : Видавництво “Світ знань”, 2002. 528 с.

4. Кондратенко Н.О. Стратегія ресурсозбереження регіональних економічних систем : монографія / Н.О. Кондратенко. Харків: НТМ, 2010. 362 с.

5. Мазаракі А.А. Основу менеджменту : підручник для студентів вищих навчальних закладів / А.А. Мазаракі, О.Й. Кузьмін, О.Г. Мельник та інші; для замовлення. А.А. Мазаракі. Харків : Фоліо, 2014. 846 с.

6. Мельник Т.М. Імпортозалежність економіки України і пріоритети селективного імпортозаміщення / Т.М. Мельник, К.С. Пугачевська. Економіка Украӥни. 2016. № 4. С. 29-44.

7. Сотник I.M. Ресурсозбереження та економічний розвиток України: формування механізмів переходу суб'єктів господарювання України до економічного розвитку на базі ресурсозберігаючих технологій : монографія / [І.М. Сотник, Л.Г. Мельник, М.К. Шапочка та ін.] ; за заг. ред. к.е.н., доц. І.М. Сотник. Суми : ВТД «Університетська книга», 2006. $551 \mathrm{c}$.

8. Зовнішня торгівля України товарами та послугами у 2010-2014 роках : статистичний збірник. Київ, 2016. Режим доступу: http://www.ukrstat.gov.ua (дата звернення: 10.09.2020). 